\title{
Bacterioplankton summer dynamics in a maritime Antarctic lake
}

\author{
Juan Antonio Villaescusa ${ }^{1}$, Carlos Rochera ${ }^{1}$, David Velázquez ${ }^{2}$, Eugenio Rico ${ }^{3}$, Antonio \\ Quesada $^{2}$ and Antonio Camacho,*
}

${ }^{1}$ Cavanilles Institute for Biodiversity and Evolutionary Biology, University of Valencia, Spain.

${ }^{2}$ Department of Biology, Autonomous University of Madrid, Spain.

${ }^{3}$ Department of Ecology, Autonomous University of Madrid, Spain.

* Corresponding author: antonio.camacho@uv.es

Received: 4/11/12 Accepted: 3/7/13

\begin{abstract}
Bacterioplankton summer dynamics in a maritime Antarctic lake

Maritime Antarctica shows less severe weather conditions than continental Antarctica, thereby allowing an important thaw process during the austral summer that increases both light availability for primary production and the inputs of nutrients and organic matter through run-off. Thus, a rapid development of certain phytoplankton groups is favoured at the beginning of the austral summer as a direct effect of the higher availability of light and nutrients after the ice thaw. Inputs of allochthonous organic matter from microbial mats and moss carpets distributed across the catchment also enhance the abundance of heterotrophic bacterioplankton. Indeed, the bacterioplankton abundance and the availability of organic matter are correlated for each studied depth, revealing a possible differential use of the organic matter. Additionally, the availability and dynamics of different types of dissolved organic matter (autochthonous and allochthonous) may influence the diversity and abundance of the different bacterioplankton groups along the water column and throughout the summer, with a relative abundance of each group that differs between the surface and bottom waters. The study of DGGE patterns reveals the existence of changes in the abundance of different bacterial taxa during the summer and the different relative importance of each bacterial group at each depth. This result can also be related to the organic matter dynamics during the austral summer, as evidenced by the correlation between the concentration of chromophoric dissolved organic matter (CDOM) and abundance of bacterioplankton at each depth. Therefore, the regional temperature regime, which allows ice thaw of the lakes and their catchments during summer, plays a key role in the onset of biological processes and the length of the productive season throughout the austral summer.
\end{abstract}

Key words: Maritime Antarctic Lakes, Summer Dynamics, Bacterioplankton, CDOM, Temperature, Bacterial Diversity.

\section{RESUMEN}

\section{Dinámica estival del bacterioplancton en un lago de la Antártida marítima}

La Antártida marítima muestra condiciones climáticas menos severas que las de la Antártida continental. Por ello, durante el verano austral, los lagos de la Antártida marítima experimentan un acusado proceso de deshielo, que conlleva un aumento de la disponibilidad de luz para los productores primarios y un incremento de las entradas de nutrientes y materia orgánica por escorrentía. Como efecto directo del aumento de la disponibilidad de luz y nutrientes tras el deshielo se produce un rápido desarrollo de las poblaciones de fitoplancton. Además, los aportes de materia orgánica, procedentes de los tapetes microbianos y musgos distribuidos a lo largo de la cuenca del lago, suministran carbono orgánico que contribuye a incrementar la abundancia de bacterioplancton heterotrófico. La abundancia de bacterioplancton y la disponibilidad de materia orgánica presentan un alto grado de correlación cuando se comparan para las distintas profundidades del lago. La disponibilidad y la dinámica de los distintos tipos de materia orgánica (autóctona y alóctona) influencian la diversidad y la abundancia de los diferentes grupos de bacterioplancton a lo largo de la columna de agua, cuya abundancia relativa difiere entre la parte superficial y profunda del lago durante el verano. El estudio de los patrones electroforéticos en las DGGE revela también la existencia de cambios en la abundancia de los diferentes grupos de taxones a lo largo del verano para las diferentes profundidades estudiadas, y la diferente importancia relativa de los grupos bacterianos en dichas profundidades. Este resultado puede estar relacionado con la dinámica de la materia orgánica durante el verano austral, lo que se evidencia por la correlación entre la concentración de materia orgánica cromofórica (cDOM) y la abundancia de bacterioplancton 
para cada profundidad. Por lo tanto, el régimen de temperatura de esta región, que permite el deshielo estival de los lagos y sus cuencas, juega un papel clave en la dinámica de los procesos biológicos determinando la duración del periodo productivo durante el verano austral.

Palabras clave: Lagos de la Antártida Marítima, Dinámica Estival, Bacterioplancton, CDOM, Temperatura, Diversidad Bacteriana.

\section{INTRODUCTION}

Livingston Island (South Shetland Islands), which is located in the maritime Antarctic region, displays a less extreme climate than continental Antarctica (Vincent, 2000; Bañón et al., 2001; Convey, 2011), allowing many water bodies (lakes, ponds, pools and streams) to be free of ice during the austral summer (Rochera et al., 2010). Byers Peninsula, located on Livingston Island, is one of the largest ice-free areas of this maritime region of the continent (SCAR 2003) exhibiting a high number of aquatic ecosystems (Toro et al., 2007; Villaescusa et al., 2010). Previous studies in Byers (Fernández-Valiente et al., 2007; Toro et al., 2007) and in other areas of maritime Antarctica (Ellis-Evans, 1996; Schiaffino et al., 2009) have revealed the existence of a strong relationship between these lakes and their landscape via runoff from the catchment. Additionally, these lakes are particularly sensitive to temperature changes, which are reflected in the timing of the ice-free period, thus affecting the length of the productive season (Rochera et al., 2010).

Pelagic production in permanently icecovered lakes is mainly based on the internal carbon supply, as observed in the continental region of Antarctica (Azam et al., 1991). In these lakes, phytoplankton dynamics respond mainly to over-wintering strategies, such as mixotrophy or resting-stage forms (McKnight et al., 2000). However, maritime Antarctic lakes receive important allochthonous inputs of inorganic nutrients and organic matter that can support lake productivity (Camacho, 2006; Schiaffino et al., 2011), favouring the uncoupling between the internal primary production and secondary production (Thingstad, 2000), particularly in catchments with microbial mats. Additionally, the existence of benthic mosses covering the lake bottom (Toro et al., 2007; Villaescusa et al., 2013) can provide an alternative source of organic matter to the pelagic community.

Both allochthonous and benthic inputs of organic matter may affect the heterotrophic bacterioplankton community structure in Antarctic lakes, demonstrating the relevance of the trophic status over the microbial community structure in these lakes (Villaescusa et al., 2010). These allochthonous inputs can also represent an important parameter for explaining differences in the taxonomic bacterial composition throughout the water column. Changes in the bacterioplankton community structure during the holomixis period are commonly displayed by Antarctic lakes and are associated with an increase in the levels of nutrient input and in the timing and length of the lake ice cover (Pearce, 2005). The present study aims to explore the relationship between different limnological factors of Antarctic lakes and the bacterioplankton dynamics during the austral summer in Lake Limnopolar as a model lake, highlighting the relevance of the different compartments that subsidize the organic supply to the water column.

\section{MATERIALS AND METHODS}

\section{Sampling Site}

Byers Peninsula is one of the largest ice-free areas of maritime Antarctica and is situated at the western end of Livingston Island $\left(62^{\circ} 34^{\prime} 35^{\prime \prime}\right.$ $62^{\circ} 40^{\prime} 35^{\prime \prime} \mathrm{S}$ and $\left.60^{\circ} 54^{\prime} 14^{\prime \prime}-61^{\circ} 13^{\prime} 07^{\prime \prime} \mathrm{W}\right)$, in the South Shetland Islands. The climate on Byers Peninsula is less extreme than in continental Antarctica, with mean summer temperatures of 
approximately $1-3^{\circ} \mathrm{C}$ (Bañón, 2001; Rochera et al., 2010). These summer temperatures above the melting point of water contribute to the presence of diverse open-water bodies with profusely settled planktonic and benthic microbial communities (Toro et al., 2007; Villaescusa et al., 2010).

Lake Limnopolar is a small (2.2 ha), relatively shallow (4.5 m maximum depth during the summer ice-free period) water body located in the central plateau of Byers Peninsula. The lake has a scarcely vegetated drainage watershed of $0.582 \mathrm{~km}^{2}$ that is covered mainly by microbial mats and moss carpets. Most of the catchment run-off flows into the lake through a small stream. An important feature is the occurrence of benthic mosses (Drepanocladus longifolius) covering the lake bottom. The lake food web presents a low complexity, dominated mainly by components of the microbial loop (Camacho et al., 2006; Toro et al., 2007; Rochera et al., 2010).

\section{In situ physical and chemical parameters}

Meteorological data from 2006/07 and 2008/09 Antarctic campaigns were recorded by an automatic weather station equipped with a Campbell CR10X logging unit. Fieldwork was conducted at Lake Limnopolar during two sampling periods in the austral summer of 2006/07, from November to February, and 2008/09, from December to February. The sampling site was located over the point of maximum depth. The vertical profiles of temperature, conductivity, $\mathrm{pH}$ and dissolved oxygen were obtained using a 6920 YSI multiparametric probe. The photosynthetically active radiation (PAR) profiles were measured as $\mu \mathrm{mol}$ photons $\mathrm{m}^{-2} \mathrm{~s}^{-1}$ at $0.5 \mathrm{~m}$ depth intervals using a $2 \pi$ sensor (Li-192SA), with uniform response in the range of 400-700 nm (PAR), attached to a LiCOR datalogger (Li-1000).

\section{Nutrient and biological measurements}

Water samples from three different depths $(0.5$, 2 and $4 \mathrm{~m}$ ) at every sampling event of 2006/07 and 2008/09 were collected using a hydrographic bottle (Uwitech) and 5-litre acid-washed plastic carboys, in parallel to the in situ physical-chem- ical survey at the deepest point of the lake. A fraction of each sample was rapidly filtered through glass-fibre filters (Whatman GF/F). Both the filtered water collected in plastic bottles, which was used for nutrient analyses, and the filters used for the further analysis of photosynthetic pigments, were stored at $-20{ }^{\circ} \mathrm{C}$. A portion of the remaining volume was processed for bacterioplankton counts, fixed with $2 \%$ glutaraldehyde and stored at $-20^{\circ} \mathrm{C}$. Another fraction of unfiltered water was separated in acid-washed plastic containers and also stored at $-20^{\circ} \mathrm{C}$ for the quantification of the total nitrogen and total phosphorus. The remaining water was immediately filtered through $0.2 \mu \mathrm{m}$ cellulose nitrate filters, placed in acid-washed glass bottles and fixed with $0.2 \mathrm{ml}$ of $1 \mathrm{~N} \mathrm{HCl}$ to remove the dissolved inorganic carbon; the samples were then stored for the analyses of the chromophoric dissolved organic matter (CDOM, stored at $\left.4^{\circ} \mathrm{C}\right)$ and TOC (stored frozen). Both the dissolved and particulate forms of nitrogen and phosphorus were quantified following Standard Methods (APHA, 1992). CDOM was determined using the excitation-emission matrix (EEM) method (Coble, 1996; Stedmond \& Markager, 2005) with an F-7000 Hitachi fluorimeter. Two forms of CDOM were described: autochthonous organic matter as protein-like CDOM (excitation-emission of 280-344 nm), which was quantified using bovine serum albumin (BSA) standards, and allochthonous organic matter as terrestrial humic acid ("THA") CDOM (excitation-emission of 250-412 nm and 250-448 nm), which was quantified using quinine-sulphate (SQ) standards (Villaescusa et al., 2010). The THA concentration primarily reflects the allochthonous input of organic matter from the catchment (i.e., microbial mats and mosses) and from the briophytic in-lake community.

Photosynthetic pigment analyses were performed by HPLC, as described by Pickney et al. (1996) and Fernández-Valiente et al. (2007). The concentrations of these photosynthetic pigments were used to define the structure of the phytoplankton community in the lake. The chlorophyll- $a$ concentration was used as a marker for the trophic status of the lake (Jeffrey et al., 1997). Fucoxanthin was used as a marker of the 
diatoms (Bacillariophyceae) abundance and can similarly be used as a marker for chrysophytes (Chrysophyceae), which are significant members of the phytoplankton in Antarctic lakes. Lutein was used as a marker of the prasinophytes (Prasinophyceae) abundance (Jeffrey et al., 1997).

Bacterioplankton counts were performed using flow cytometry. Aliquots of $1 \mathrm{ml}$ water samples, previously fixed in $2 \%$ glutaraldehyde, were incubated for $20 \mathrm{~min}$. at room temperature and then stained with SYBR Green-I. The samples were analysed using a Beckman Coulter flow cytometer (Cytomics FC 500 MPL) with five fluorescent channels, following the procedures described by Gasol \& del Giorgio (2000).

\section{Fluorescence in situ hybridisation (FISH) and DGGE analyses}

Changes in the diversity of the main bacterial groups present in the studied Antarctic lake were monitored during the summer of 2008/09 at every sampled depth $(0.5,2$ and $4 \mathrm{~m})$ using FISH analysis. Samples fixed with $2 \%$ formaldehyde were previously filtered through $0.2 \mu \mathrm{m}$ white polycarbonate filters (Whatman); the FISH hybridisation process followed Cottrel \& Kirchman (2003). Although this method has directly been used in the characterisation of Antarctic lakes (Pearce, 2003), different limitations are implied and should be considered, such as those mentioned in the Discussion section. DAPI was used to count the total bacteria for comparison with the FISH analysis. The probes used for the monitoring were focused on the different groups previously described as dominant in Antarctic lakes (Pearce, 2003) and particularly in Lake Limnopolar (Villaescusa et al., 2010). The probes used were as follows: a general probe for Bacteria (Eub338, 5'-GCTGCCTCCCGTAGGA GT-3'), alpha-Proteobacteria (Alf1b, 5'-CGTTC GYTCTGAGCCAG-3'), beta-Proteobacteria (Bet 42a, 5'-GCCTTCCCACTTCGTTT-3'), gammaProteobacteria (Gam42a, 5'-GCCTTCCCACAT CGTTT-3') and Bacteroidetes (CF319a, 5'-TGG TCCGTGTCTCAGTAC-3').

To describe the changes in the bacterial structure during the summer and the differences within the vertical profile, a DGGE (Denaturing Gradient Gel Electrophoresis) profile was performed for the three last sampling dates of the summer of 2008/09. The methods used for DNA extraction and amplification and the DGGE fingerprinting of microbial community are described in Villaescusa et al. (2010). A matrix with the per cent contribution of each band to the total of that lane was built for the different DGGE lanes; the per cent contribution

Table 1. Meteorological conditions in Byers Peninsula during the summers of 2006/07 and 2008/09. Max and Min refer to the average of the maximum and minimum daily values. The 2001/04 data show the average values for the summer period of three years between 2001-2004 (Rochera et al., 2010). Características meteorológicas de la Península Byers durante los veranos 2006/07 y 2008/09. Los valores Máx y Mín reflejan los valores promedio de las máximas y mínimas de cada día. El dato para 2001/04 refleja el valor promedio de tres veranos comprendidos entre los años 2001-2004 (Rochera et al., 2010).

\begin{tabular}{|c|c|c|c|c|c|c|c|}
\hline Summer & $\begin{array}{l}\text { Air temp. } \\
\quad\left({ }^{\circ} \mathrm{C}\right)\end{array}$ & $\begin{array}{l}\text { Soil temp. } \\
\quad\left({ }^{\circ} \mathrm{C}\right)\end{array}$ & $\begin{array}{c}\text { Water temp. } \\
\left({ }^{\circ} \mathrm{C}\right)\end{array}$ & $\begin{array}{c}\text { Radiation } \\
\left(\mathrm{Kj} \mathrm{m}^{-2}\right)\end{array}$ & $\begin{array}{c}\text { Wind speed } \\
\left(\mathrm{km} \mathrm{h}^{-1}\right)\end{array}$ & $\begin{array}{l}\text { Max wind speed } \\
\qquad\left(\mathrm{km} \mathrm{h}^{-1}\right)\end{array}$ & $\begin{array}{c}\text { Ice free period } \\
\text { (days) }\end{array}$ \\
\hline $2006 / 2007$ & & & & & & & 95 \\
\hline Mean & 1.2 & 2.1 & 4.2 & 14350 & 24 & 51 & \\
\hline Max & 3.2 & 6.0 & 9.7 & 29985 & 46 & 95 & \\
\hline Min & -0.3 & -0.3 & -0.2 & 3735 & 10 & 25 & \\
\hline $2008 / 2009$ & & & & & & & 115 \\
\hline Mean & 1.4 & 2.1 & 4.3 & 14520 & 25 & 34 & \\
\hline Max & 5.3 & 8.5 & 12.9 & 27750 & 56 & 86 & \\
\hline Min & -2.0 & -2.1 & 1.2 & 4615 & 1 & 4 & \\
\hline $2001 / 2004$ & & & & & & & 69 \\
\hline Mean & 0.9 & 1.3 & 3.1 & 12474 & 23 & 51 & \\
\hline Max & 5.2 & 8.4 & 12.4 & 28565 & 48 & 111 & \\
\hline Min & -5.0 & -4.4 & -0.9 & 1491 & 8 & 19 & \\
\hline
\end{tabular}




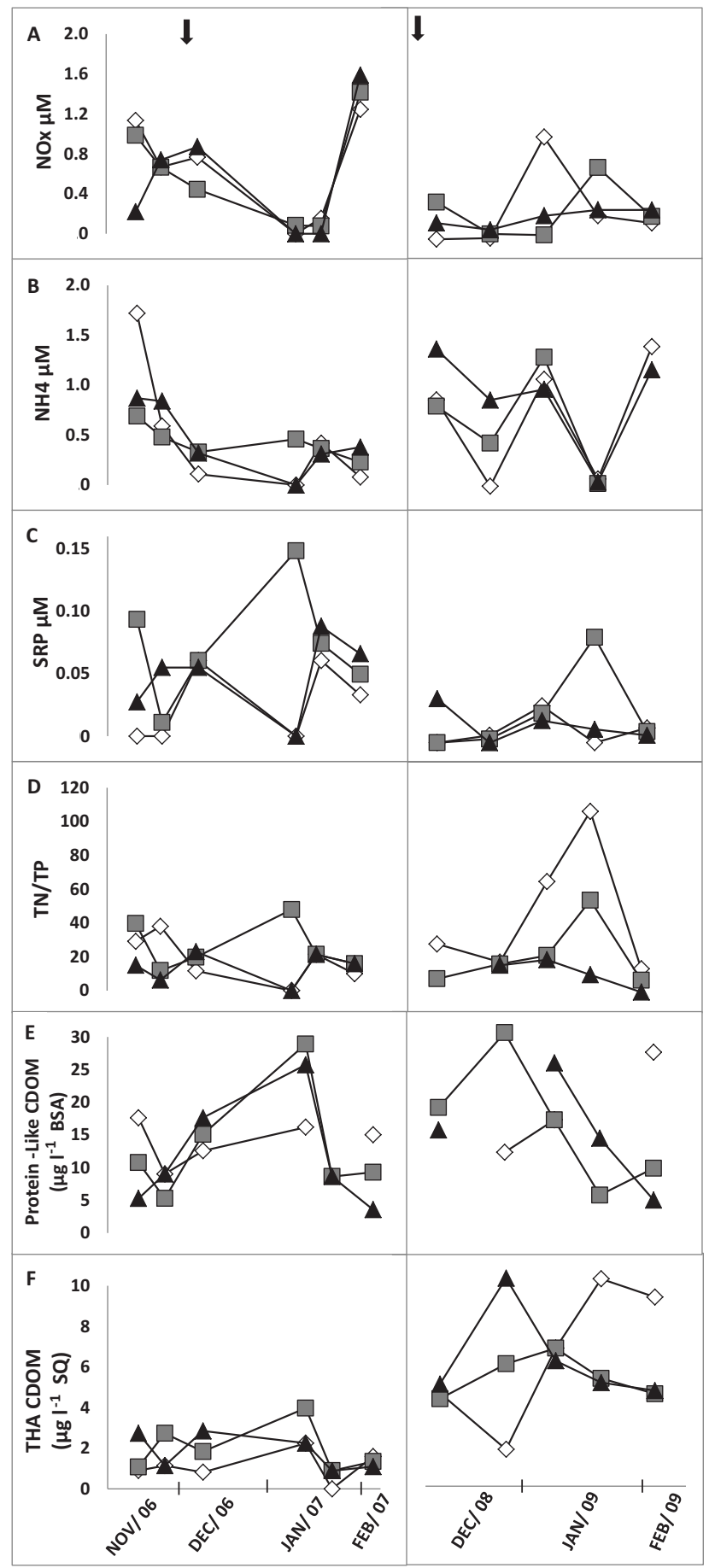

Figure 1. Dynamics of the main chemical parameters at three different depths (diamond $=0.5 \mathrm{~m}$; square $=2 \mathrm{~m}$; triangle $=$ $4 \mathrm{~m}$ ) in Lake Limnopolar during the summer periods of 2006/07 and 2008/09. A $\left(\mathrm{NO}_{x}\right), \mathrm{B}\left(\mathrm{NH}_{4}^{+}\right), \mathrm{C}$ (SRP), D (Total N/Total P), E (protein-like CDOM) and F (THA CDOM). The arrows indicate the date of ice melt. Dinámica de los parámetros químicos para tres profundidades diferentes (rombo $0.5 \mathrm{~m}$, cuadrado $2 \mathrm{~m}$ y triangulo $4 \mathrm{~m}$ ) en el lago Limnopolar durante el verano de $2006 / 07 \mathrm{y}$ 2008/09. A $\left(\mathrm{NO}_{\mathrm{x}}\right), \mathrm{B}\left(\mathrm{NH}_{4}^{+}\right), \mathrm{C}(\mathrm{SRP}), \mathrm{D}$ (Total N/Total P), E (Protein-like CDOM) y F (THA CDOM). Las flechas indican la fecha en la que se produjo el deshielo. 
of each band was calculated using an image analysis programme based on the light intensity profile for each lane (Díez et al., 2001). A dendrogram based on this matrix was developed using an average linkage method (UPGMA, unweighted pair group method with arithmetic mean).

\section{Statistical analyses}

The results for the physical-chemical and biological variables for the two years sampled (06/07 and 08/09) were compared using a Principal Component Analysis (PCA) including the data for the three depths sampled $(0.5,2$ and $4 \mathrm{~m})$ and for all the sampling dates. Another PCA analysis using the per cent of each group measured in the FISH analysis was also performed to study the distribution of the different groups along the water column.

\section{RESULTS}

The meteorological data from Byers Peninsula during the studied period are shown in Table 1. The summer of 2008/09 showed a slightly higher average air temperature, approximately $0.2{ }^{\circ} \mathrm{C}$ warmer than 2006/07, and the average maximum and minimum temperatures in 2008/09 showed higher and lower values, respectively. These characteristics reflect a more extreme $2008 / 09$ summer in comparison to $2006 / 07$. The temperature during these two years was warmer compared to the summer periods of 2001 through 2004 (Table 1), and this increase in temperature was also observed in the higher duration of the ice-free period compared to the 2001-2004 summer periods. During 2006/07, the ice melted at the beginning of December, and the lake remained free of ice for a period of 95 days; during 2008/09, the ice cap melted completely during November, and the lake remained ice free for a period of 115 days. At the end of December (already the ice-free period) in both years, approximately $5-20 \%$ of the superficial incident light reached the lake bottom, and the total irradiance reaching the lake bottom significantly increased to $30 \%$ by the end of January in both years. The water temperature and conductivity profiles in both summers were characterised by relatively uniform values along the water column (data not shown).

The dissolved inorganic nitrogen (DIN) concentrations $\left(\mathrm{NO}_{x}^{-}+\mathrm{NH}_{4}^{+}\right)$were near the detection limits throughout the sampling periods of both years, usually below $2 \mu \mathrm{M}$ (Fig. 1A and 1B). During the ice-free period of 2006/07, the highest concentrations of DIN were measured at the beginning of February, mainly dominated by oxidised forms $\left(\mathrm{NO}_{x}^{-}\right)$, and in the 2006/07 summer season soluble reactive phosphorus (SRP) concentrations varied from undetectable levels $(<0.03 \mu \mathrm{M})$ to a maximum of $0.149 \mu \mathrm{M}$ by mid-January. Conversely, during the summer 2008/09 SRP concentrations were lower, with maximum values approximately $0.08 \mu \mathrm{M}$ at the end of January. Concerning the possible existence of a vertical gradient of nutrient concentrations, an increase in the SRP concentration was detected in the $2 \mathrm{~m}$ samples of mid-January in both years. However, no significant differences in depth throughout the summer were detected for the remaining samples analysed. The TN/TP molar ratios were lower (between 6 and 48) during 2006/07 compared to the summer of 2008/09, a time when the values were above 60 in mid-January.

The fluorometric CDOM analyses showed that the protein-type concentrations did not exceed $30 \mu \mathrm{g}^{-1}$ BSA for both years (Fig. 1E). The highest concentrations appeared after the ice melt, specifically in the deeper samples (2 and $4 \mathrm{~m}$ ), most likely due to an increase in the lake primary production, as shown by an increase in phytoplankton abundance. The proteintype CDOM concentration was homogeneous throughout the water column during the remainder of the sampling period. The terrestrial humic CDOM "THA" (Fig. 1F) concentrations were different in both years. The THA concentration was stable along the summer of 2006/07 and did not exceed values of $4 \mu \mathrm{g} \mathrm{l}^{-1} \mathrm{SQ}$. However, the THA concentration pattern during 2008/09 showed higher values, with a maximum of $10 \mu \mathrm{g}$ $1^{-1} \mathrm{SQ}$. For this year, the THA measurements during December were higher at the bottom of the lake, whereas the THA peak was measured in the upper layers at the end of January. 


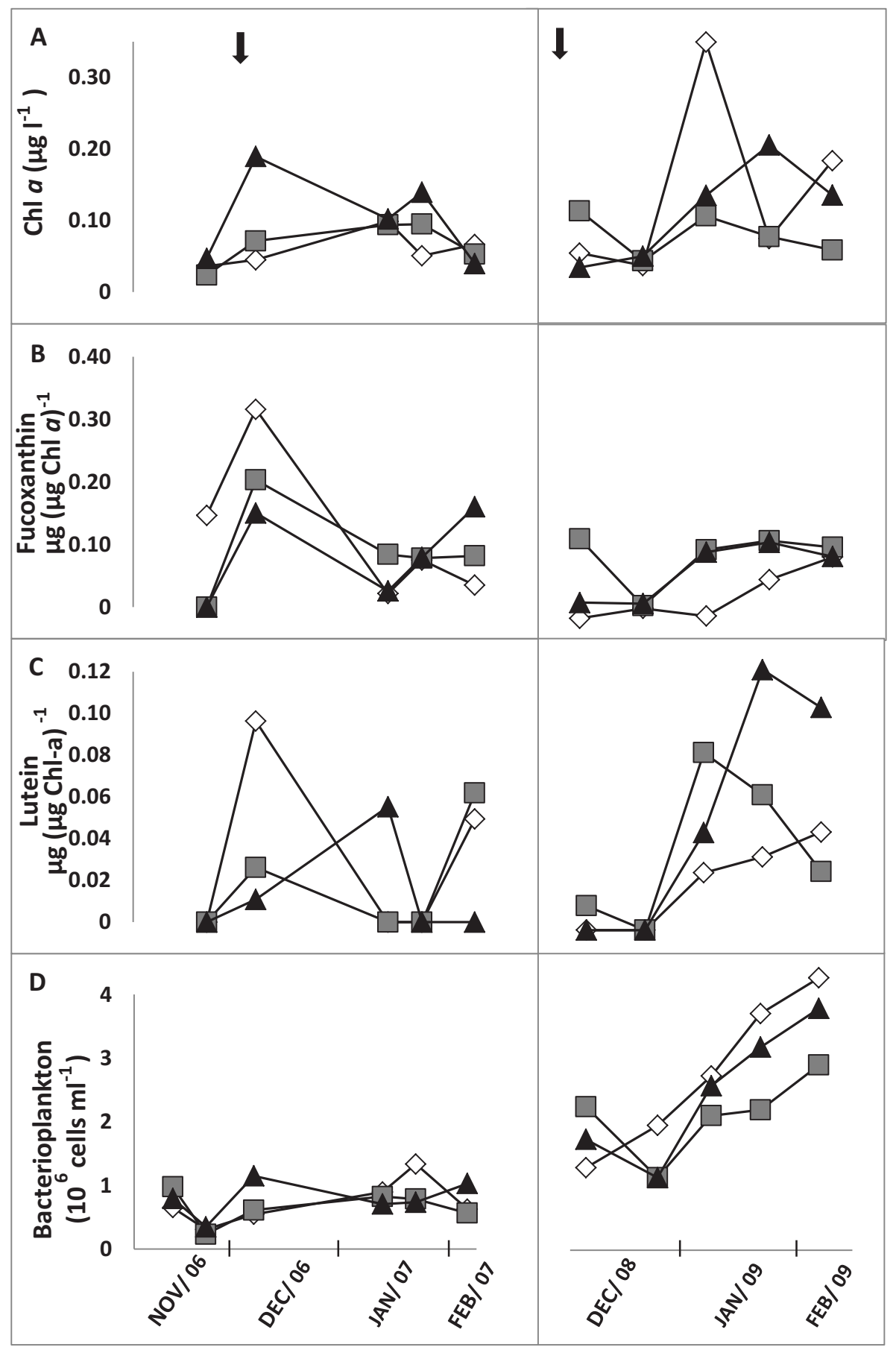

Figure 2. Dynamics of the photosynthetic pigments concentrations and abundance of heterotrophic bacterioplankton at three different depths (diamond $=0.5 \mathrm{~m}$; square $=2 \mathrm{~m}$; triangle $=4 \mathrm{~m}$ ) in Lake Limnopolar during the summer periods of 2006/07 and 2008/09. A (Chl- $a$ ), B (fucoxanthin/Chl- $a$ ratio), C (lutein/Chl- $a$ ratio), D (bacterioplankton abundance). The arrows indicate the date of ice melt. Dinámica de la concentración de pigmentos fotosintéticos y abundancia de bacterioplankton heterotrófico para tres profundidades diferentes (rombo $0.5 \mathrm{~m}$, cuadrado $2 \mathrm{~m}$ y triangulo $4 \mathrm{~m}$ ) en el lago Limnopolar durante el verano de 2006/07 y 2008/09. A (Chl-a), B. (ratio Fucoxantina/Chl-a), C (ratio Luteina/Chl-a), D (Abundancia de bacterioplancton). Las flechas indican la fecha en la que se produjo el deshielo. 
The phytoplankton biomass (Fig. 2A), measured as the concentration of chlorophyll- $a$ (Chl- $a$ ), was very low in both of the studied seasons, with an average summer concentration of $0.07 \mu \mathrm{g}^{-1}$ in 2006/07 and $0.1 \mu \mathrm{g}^{-1}$ in 2008/09. During 2006/07, the maximum values of Chl- $a$ concentration were observed in the bottom layers after the ice cap thaw at the beginning of January. However, this early-summer increase in Chl- $a$ concentration was not detected in 2008/09, most likely due to an anticipated ice cap thaw during this year. Conversely, an increase in the Chl- $a$ concentration occurred in the surface layers during mid-January (2008/09 summer) and at the lake bottom at the end of January. The concentrations of the main taxa-specific carotenoids are shown in Fig. $2 \mathrm{~B}$ and 2C. The fucoxanthin concentration, which was used as a marker for diatoms and chrysophytes, showed different patterns in both summers. During 2006/07, the ratio between fucoxanthin/Chl- $a$ showed an increase immediately following the ice melt; however, it suffered a slight decrease during the rest of the summer, reaching concentrations of $0.03 \mu \mathrm{g}$ fucoxanthin $(\mu \mathrm{g} \mathrm{Chl}-a)^{-1}$. In contrast, this increase after the ice cap thaw was not observed during 2008/09, and the fucoxanthin concentration (as a ratio to Chl- $a$ ) was stable throughout the summer, with average values of $0.1 \mu \mathrm{g}$ fucoxanthin ( $\mu \mathrm{g} \mathrm{Chl}-a)^{-1}$. The lutein concentration as a ratio to $\mathrm{Chl}-a$, which was used as a marker of prasinophytes, was relatively stable during the summer of 2006/07, with average values of lutein/Chl- $a$ of $0.04 \mu \mathrm{g}$ lutein ( $\mu \mathrm{g}$ Chl- $a)^{-1}$. However, after the ice melt, an increase in the surface concentration was registered, with maximum values of $0.10 \mu \mathrm{g}$ lutein ( $\mu \mathrm{g}$ Chl- $a)^{-1}$. During 2008/09, this ratio increased by mid-January, mainly in the bottom samples, reaching values of $0.12 \mu \mathrm{g}$ lutein $(\mu \mathrm{g} \text { Chl- } a)^{-1}$.

The bacterioplankton abundance showed significant differences between the two years studied (Fig. 2D). During 2006/07, the bacterial abundance showed constant average values of approx. $1 \cdot 10^{6}$ cell $\mathrm{ml}^{-1}$ during the summer. However, during the sampling period of 2008/09, the bacterial abundance showed a progressive increase from $1 \cdot 10^{6}$ cell $\mathrm{ml}^{-1}$ in December to $4 \cdot 10^{6}$ cell $\mathrm{ml}^{-1}$ at the end of January and beginning of February. Nonetheless, the bacterial abundance throughout the water column was comparatively homogeneous within the vertical profile for both years, though the distribution of the dominant groups was not.

The results for the 2008/09 FISH analyses showed hybridisation levels for EUB338 between $64 \%$ at 0.5 and $2 \mathrm{~m}$ and $53 \%$ at $4 \mathrm{~m}$ when compared to the bacterial counts according to DAPI staining. The identification and quantification of the main groups of bacteria were possible using the available set of probes. The percentage of each group at the different depths is shown in Fig. 3A. Remarkably, the addition occasionally amounted to even more than $100 \%$ of the DAPI-stained cells due to a slight lack of specificity of the probes that would led to double counting by FISH. The abundance distribution among the different groups showed some differences among the groups studied: beta-Proteobacteria and Bacteroidetes were the most abundant in the lake, whereas gammaProteobacteria was least abundant at all depths; alpha-Proteobacteria showed a higher abundance only for the $0.5 \mathrm{~m}$ samples. The results of the heterogeneous vertical distribution were also supported by a PCA analysis (Fig. 3B) that separated the four groups (alpha, beta, gamma and Bacteroidetes) by a "depth" axis (82\% of variance). In this analysis, alpha-Proteobacteria was grouped with the surface samples, beta and gamma-Proteobacteria were grouped with the deeper samples, and Bacteroidetes (C-F) appeared in a middle position due to its higher abundance in the mid-depth lake samples.

The DGGE profiles for the samples of the 2008/09 Antarctic campaign are shown in Fig. 4. Although the pattern of band diversity for each depth in Lake Limnopolar was relatively similar during the summer, the DGGE profiles showed differences in band intensity. The band intensity matrix analysed by a Euclidean distance dendrogram, grouped similar band patterns for each depth and date analysed. For the first sampling date (January $10^{\text {th }}, 2009$ ) the grouping of the band profiles of the three depths described a homogeneous distribution. The other two sampling 

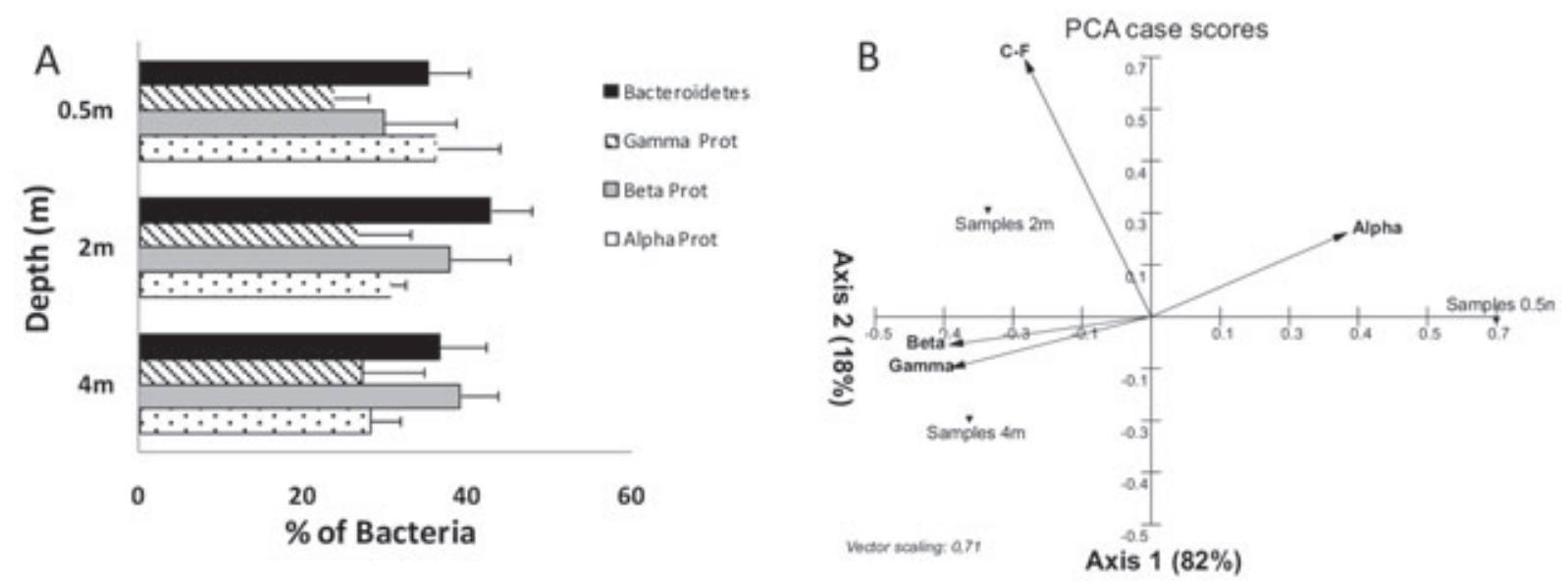

Figure 3. A) Relative dominance of the main bacterial groups found at different depths of Lake Limnopolar during the austral summer 2008/09 using FISH counts. B) Biplot corresponding to the Principal Components Analysis of the 2008/09 FISH samples for the different depths sampled. The values shown correspond to the average value of the samples at each depth. A) Dominancia relativa de los principales grupos bacterianos para diferentes profundidades del lago Limnopolar a lo largo del verano austral 2008/09 utilizando recuentos mediante FISH. B) Gráfico mostrando el resultado del Análisis de Componentes Principales sobre los resultados de FISH para muestras de diferentes profundidades tomadas durante la campaña 2008/09. Los valores representados corresponden al valor promedio de las muestras de cada profundidad.

dates (January 21 ${ }^{\text {st }}, 2009$, and February $2^{\text {nd }}$, 2009) showed a different group classification. For the second sampling date (January $21^{\text {st }}$, 2009), the bottom sample (4 m) appeared clearly separated from the other depths $(0.5$ and $2 \mathrm{~m})$, reflecting a change in the band pattern of the lake bottom sample; for the last date (February $\left.2^{\text {nd }}, 2009\right)$, the samples of the middle and bottom depths (2 and $4 \mathrm{~m}$ ) appeared clearly grouped, showing a different pattern compared to that of the surface sample.

The principal component analysis (PCA) for the environmental data of the two sampled years (Fig. 5) showed significant differences among

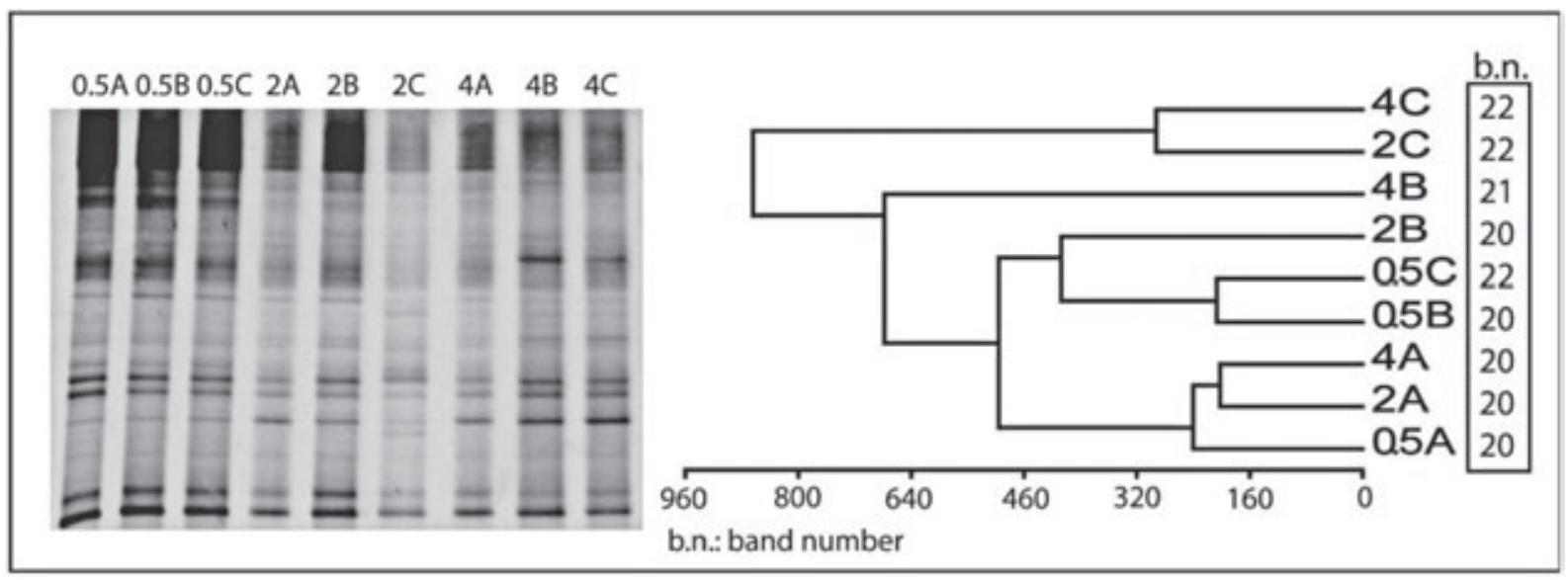

Figure 4. Dendrogram of the Euclidean distances between different DGGE profiles obtained at Lake Limnopolar at three different depths $(0.5,2$ and $4 \mathrm{~m})$ during the 2008/09 summer. The letters indicate the three different sampling dates: A (January 10 ${ }^{\text {th }}, 2009$ ), B (January $\left.21^{\text {st }}, 2009\right)$ and C (February $\left.3^{\text {rd }}, 2009\right)$. b.n. $=$ number of bands. Dendrograma de distancias euclídeas entre perfiles de $D G G E$ de diferentes profundidades $(0.5,2$ y $4 \mathrm{~m})$ en el lago Limnopolar durante el verano 2008/09. Cada una de las letras refleja las diferentes fechas de muestreo: A (10-1-09), B (21-1-09) y C (3-2-09). b.n. = número de bandas. 


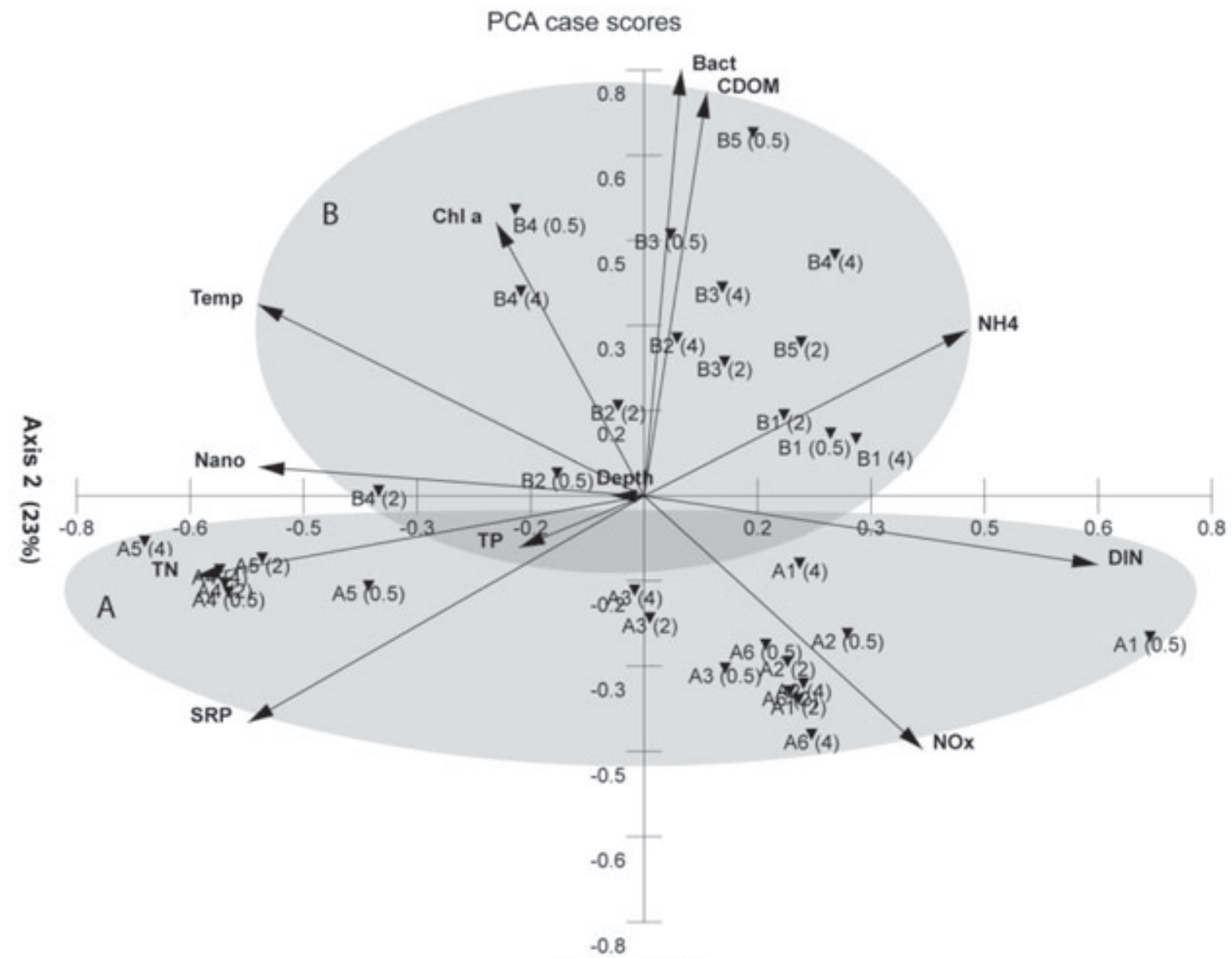

Axis $1(27 \%)$

Figure 5. Biplot corresponding to the Principal Components Analysis for two years $(A=06 / 07 ; B=08 / 09)$. Lake Limnopolar samples enumerated by sampling order by date (1-6) and depth $(0.5,2$ and $4 \mathrm{~m})$. The variables shown are as follows: Depth (maximum depth), Temp (temperature), Chl $a$ (chlorophyll concentration), Bact (bacterial abundance), Nano (nanoplankton abundance), CDOM (chromophoric dissolved organic matter), $\mathrm{NH}_{4}$ (ammonium), $\mathrm{NO}_{x}$ (oxidised inorganic nitrogen forms), DIN (dissolved inorganic nitrogen), SRP (soluble reactive phosphorus), TN (total nitrogen), TP (total phosphorus). Note that first component is plotted on the vertical axis. Gráfico mostrando el Análisis de Componentes Principales para dos años (A “06-07” y B “08-09”). Las muestras del Lago Limnopolar quedan enumeradas por orden de muestreo 1-6 y profundidad (0.5, 2 y 4 m). Las variables son: Depth (profundidad máxima), Temp (temperatura), Chl a (concentración de clorofila), Bact (abundancia de bacterias), Nano (abundancia de nanoplancton), $\mathrm{CDOM}$ (materia orgánica disuelta cromófora), $\mathrm{NH}_{4}$ (amonio), $\mathrm{NO}_{\mathrm{x}}$ (formas oxidadas de nitrógeno), DIN (nitrógeno inorgánico disuelto), SRP (fósforo reactivo soluble), TN (nitrógeno total) y TP (fósforo total). Nótese que la primera componente está representada en el eje vertical.

the years. Axis $1(27 \%)$ separated both years with a clear biological-biochemical component (bacterial abundance and CDOM concentration), though a correlation analysis between the bacterial abundance and CDOM concentration did not display significant differences, with a 0.073 correlation factor $(\alpha=0.05, p=0.314)$. However, correlation analyses comparing the average values for the five sampling events and separately for each depth showed significant differences among them when the depth was considered for grouping, with a correlation factor of $0.85(\alpha=0.05, p=0.042)$. Although the PCA analysis with environmental variables (Fig. 5) did not show clear differences between the different depth samples, the PCA analysis for 
the 2008/09 FISH results (Fig. 3B) showed differences in the bacterial composition with depth: a higher abundance of alpha-Proteobacteria in the surface samples, and Bacteroidetes (C-F in Fig. 3B) and beta-Proteobacteria most abundant in the middle and deep layers, respectively.

\section{DISCUSION}

The results from this work together with data from previous studies (Rochera et al., 2010), are an example of how changes in major physical factors related to climate may drive the functioning of the studied lake. The meteorological data show that the 2006/07 and 2008/09 summers were slightly warmer than the previously monitored years of 2001-2004 (Rochera et al., 2010) and that the mean solar radiation was also higher. These results reflect a high variability in the meteorological conditions in this area for different years. It has been demonstrated that variation in meteorological conditions largely influences the length of a lake ice-free period (Rochera et al., 2010) and may cause important changes in the inputs of inorganic nutrients and organic matter from the catchment, thereby directly affecting the microbial structure of the lake (Pearce, 2005). The 2008/09 period (Table 1) showed a warmer and extreme summer, with a higher average maximum temperature and lower minimum temperature, reflecting the highest range of variation for this season. Higher temperatures could provoke an advance in the ice melt and favour an increase in nutrient and organic matter inputs into the lake, thus enhancing microbial activity and altering the productive period of the phytoplankton and aquatic mosses within the lake, as well as moss carpets and microbial mats that cover wide areas of the lake catchment (Fernández-Valiente et al., 2007). Because the length of the productive period in maritime Antarctic lakes during the austral summer is controlled by the date of the ice melt in the lake, very low productive seasons, such as the 2003/04 summer (Rochera et $a l ., 2010$ ), or long productive periods, such as the 2008/09 summer, can occur.
The low nutrients, Chl- $a$ and carotenoid concentrations reveal that Lake Limnopolar exhibits ultra-oligotrophic characteristics. Such nutrient scarcity has been reported for Byers Peninsula lakes located in the central plateau (Toro et al., 2007; Villaescusa et al., 2010) and for other inland maritime Antarctic lakes (Drago, 1989; Izaguirre et al., 2003). The carotenoid ratios showed the existence of a change in the relative importance of the different algal groups during the summer. The increase in the fucoxanthin/Chl$a$ ratio immediately following the ice melt during 2006/07 reveals an increase in the abundance of chrysophytes and diatoms in the lake as a response to the increase in light and nutrient availability, in addition to an input of benthic diatoms from the catchment. This increase was not recorded in the 2008/09 summer due to an anticipated melting of the ice cap. Additionally, the strong increase in the lutein/Chl- $a$ ratio in the surface samples after the ice meilting 2006/07 reflects the response of the prasinophytes to increased light and nutrient availability. This massive increase in algal abundance after the ice melt has also been reported in studies of the viral diversity in the lake, which showed a high diversity of phytophagous viruses after the ice melt (López-Bueno et al., 2009).

The marked differences in the bacterioplankton abundance during the two years surveyed could be related to the availability of organic carbon and the length of the ice-free period. Despite the inexistence of a statistically significant correlation between the bacterioplankton abundance and CDOM when all the samples were considered together, a statistically significant correlation appeared when the average values for each depth during the summer of 2008/09 were compared by considering the depths separately. This could demonstrate a different response of the bacterial community to the allochthonous and/or moss-produced CDOM (THA) at each depth. This evidence can be supported by the study of the bacterioplankton diversity in Lake Limnopolar using clone libraries (Villaescusa et al., 2013), demonstrating the existence of a biological gradient in the bacterial community 
diversity, which may be responding differentially at each depth. Additionally, the evident differences between the 2006/07 and 2008/09 summers, as shown in the PCA analysis (Fig. 5), are linked to a higher abundance of organic matter and bacterioplankton. In addition to these factors, the selective effect of temperature and zooplankton predation could also exert a parallel control over the bacterioplankton community (Camacho, 2006). The allochthonous THA CDOM concentration during the 2006/07 summer was stable, as was the bacterioplankton abundance (Figs. 1 and 2), reflecting a comparatively stable season. However, the abundance of allochthonous THA CDOM along the water column was not homogeneous during the 2008/09 summer, and the higher CDOM concentration found in the lake bottom after the ice melt might be the result of a higher photosynthetic activity by benthic mosses (Toro et al., 2007; Li et al., 2009) promoted by the increase in light availability. However, the evident increase in THA CDOM in the surface samples during the last part of the summer could be related to the activity of the catchment vegetation (Coble, 1996; Stedmond \& Markager, 2005; Velázquez et al., 2013), which, in our case, was composed mainly by microbial mats and moss carpets (Fernández-Valiente et al., 2007). Thus, bacterioplankton production in Lake Limnopolar could be enhanced by both benthic mosses and the terrestrial communities of primary producers within the catchment, albeit only partly because THA CDOM is relatively refractory to bacterial degradation. The evident differences in the abundance of autochthonous and allochthonous organic matter along the water column could influence the existence of a bacterial diversity gradient in the lake (Villaescusa et al., 2013) and, perhaps, the differential use of organic matter.

The FISH analyses of the 2008/09 summer samples showed a community largely dominated by Bacteroidetes and beta-Proteobacteria at all depths but mainly in the middle and deeper parts of the lake, respectively, and a dominance of alpha-Proteobacteria in the upper part of the lake. Despite the known limitations of the FISH method related to low specificity and signal, the existence of differences in our samples is statistically demonstrated by the results of the PCA analysis (Fig. 3B) that correctly describes the bacterial group distribution. Our results agree with other studies using FISH probes, indicating that the beta subdivision of Proteobacteria appears to be globally distributed in both non-polar (Wagner et al., 1993) and polar freshwater environments, regions where these taxa are particularly abundant (Pearce, 2003; Pearce et al., 2007).

The Euclidean distance dendrogram performed using the DGGE band intensity profile for the 2008/09 samples showed that the main bacterial taxa distribution of approx. 20-22 bands remained stable throughout the summer; however, the relative abundance of the different taxa varied along both time and depth (Fig. 4). These results demonstrate the existence of a change in the relative dominance of the different bacterial groups in the deep waters during the last part of the summer. These dynamics in bacterioplankton group abundance could be related to the observed changes in the allochthonous THA CDOM concentrations (Fig. 1F) along the water column. Therefore, the differential availability of organic matter could be influencing alterations in the abundance of the main bacterial groups (alpha, beta, gamma Proteobacteria and Bacteroidetes).

The changes in the bacterial group abundance along summer and depth, together with the known bacterial diversity differences between the upper and lower parts of the lake (Villaescusa et al., 2013), represent relevant differences in biological composition. Vertical differences in the dominance of the bacterial groups occur even though a physical stratification did not occur, as shown by the PCA analysis (Fig. 5), thus suggesting a major role of the benthic compartment (i.e., benthic mosses) and allowing the existence of a certain "biological stratification" in the system. Therefore, the organic matter produced by lacustrine benthic mosses and microbial mats within the catchment is one of the most significant factors determining the structure of the bacterioplankton community in Lake Limnopolar, as also suggested for other Antarctic lakes (Pearce, 2005).

The variation in the duration of the productive season due to an early or late ice thaw affects the inputs of nutrients and organic matter into the 
lake by run-off processes. Consequently, these dynamics produce important changes in the composition and abundance of the bacterial community. Additionally, the allochthonous input of organic matter favours the appearance of an uncoupling in the biological process in the lake relative to the available organic carbon supplied by planktonic primary production, thereby increasing the heterotrophic bacterioplankton abundance and promoting changes in its composition during summer and along the water column. The significant warming of this area (Quayle et al., 2002) provided our study with a great relevance to understand the changes that are occurring in maritime Antarctica lacustrine ecosystems.

\section{ACKNOWLEDGEMENTS}

This study was supported by the project CGL2005-06549-C02-02/ANT from the Spanish Ministry of Education and Science to AC, which was co-financed by European FEDER funds, and CGL2005-06549-C02-01/ANT to AQ. Support for travel costs was obtained from grants CGL2007-29841-E and CTM2008-05205-E, given by the Spanish Ministry of Science and Innovation to AC. The authors are indebted to their colleagues of the LIMNOPOLAR research Team for their support and to the crew of the ship Las Palmas (Spanish Navy) and the Marine Technology Unit (UTM-CSIC) for logistic support. We also thank the Central Service for the Support to Experimental Research (SCSIE) from the University of Valencia for their assistance with some of the analyses.

\section{REFERENCES}

APHA, AWWA \& WEF. 1992. Standard methods for the examination of water and wastewater, $18^{\text {th }} \mathrm{ed}$. American Public Health Association, American Water Works Association and Water Environment Federation, Washington D.C.

AZAM, F., D. C. SMITH \& J. T. HOLLIBAUGH. 1991. The role of the microbial loop in Antarctic pelagic ecosystems. In: Polar Research 10, E. Sakshaug, C.C.E. Hopkins \& N. A. Oritsland (eds.): pp. 239-243. Proceedings of the Pro Mare Symposium on Polar Marine Ecology. Trondheim.

BAÑóN, M. 2001. Observaciones meteorológicas en la Base Antártica Española Juan Carlos I. Monografía A-151, Instituto Nacional de Meteorología, Ministerio de Medio Ambiente. Madrid.

CAMACHO, A. 2006. Planktonic microbial assemblages and the potential effects of metazooplankton predation on the food web of lakes from the maritime Antarctica and sub Antarctic islands. Reviews in Environmental Science and Biotechnology, 5: 167-185.

COBLE, P. G. 1996. Characterization of marine and terrestrial DOM in seawater using excitationemission matrix spectroscopy. Marine Chemistry, 51: 325-346.

CONVEY, P. 2011. Antarctic terrestrial biodiversity in a changing world. Polar Biology, 34: 1629-1641.

COTTRELL, M. T. \& D. L. KIRCHMAN. 2003. Contribution of major bacterial groups to bacterial biomass production (thymidine and leucine incorporation) in the Delaware estuary. Limnology and Oceanography, 40: 168-178.

DÍEZ, B., C. PEDRÓS-ALIÓ, T. L. MARSH \& R. MASSANA. 2001. Application of Denaturing gradient gel electrophoresis (DGGE) to study the diversity of marine picoeukaryotic assemblages and comparison of DGGE with other molecular techniques. Applied and Environmental Microbiology, 67: 2942-2951.

DRAGO, E. C. 1989. Thermal summer characteristics of lakes and ponds on Deception Island, Antarctica. Hydrobiologia, 184: 51-60.

ELLIS-EVANS, J. C. 1996. Biological and chemical features of lakes and streams. In: Geomorphological map of Byers Peninsula, Livingston Island. J. López-Martínez, M. R. A. Thomson \& J. W. Thomson (eds.): 20-22. BAS GEOMAP Series, Sheet 5-A. British Antarctic Survey, Cambridge.

FERNÁNDEZ-VALIENTE, E., A. CAMACHO, C. ROCHERA, E. RICO, W. F. VINCENT \& A. QUESADA. 2007. Community structure and physiological characterization of microbial mats in Byers Peninsula. Livingston Island (South Shetland Islands, Antarctica). FEMS Microbiology Ecology, 59: 377-385.

GASOL, J. M. \& P. DEL GIORGIO. 2000. Using flow cytometry for counting natural planktonic bacteria and understanding the structure of planktonic bacterial communities. Scientia Marina, 64: 197-224. 
IZAGUIRRE, I., I. ALLENDE \& M. C. MARINONE. 2003. Comparative study of the planktonic communities of three lakes of contrasting trophic status at Hope Bay (Antarctic Peninsula). Journal of Plankton Research, 25: 1079-1097.

JEFFREY, S. W., R. F. C. MANTOURA \& S. W. WRIGHT. 1997. Phytoplankton pigments in oceanography: guidelines to modern methods. UNESCO, Paris.

LI, S., R. OCHYRA, P. WU, R. D. SEPPELT, M. CAI, H. WANG \& C. LI. 2009. Depranocladus longifolius (Amblystegiaceae), an addition to the moss flora of King George Island, South Shetland Islands, with a review of Antarctic benthic mosses. Polar Biology, 32: 1415-1425.

LÓPEZ-BUENO, A., J. TAMAMES, D. VELÁZQUEZ, M. ANDRÉS, A. QUESADA \& A. ALCAMI. 2009. High diversity of the viral community from an Antarctic lake. Science, 326: 585.

MCKNIGHT, D. M., B. L. HOWES, C. D. TAYLOR \& D. D. GOEHRINGER. 2000. Phytoplankton dynamics in a stably stratified Antarctic lake during winter darkness. Journal of Phycology, 36: 852861.

PEARCE, D. A. 2003. Bacterioplankton community structure in a maritime Antarctic oligotrophic lake during a period of holomixis, as determined by denaturing gradient gel electrophoresis (DGGE) and fluorescence in situ hybridisation (FISH). Microbial Ecology, 46: 92-105.

PEARCE, D. A. 2005. The structure and stability of the bacterioplankton community in Antarctic freshwater lakes, subject to extremely rapid environmental change. FEMS Microbiology Ecology, 53: 61-72.

PEARCE, D. A., C. S. COCKELL, E. S. LINDSTRÖM \& L. J. TRANVIK. 2007. First evidence for a bipolar distribution of dominant freshwater lake bacterioplankton. Antarctic Science, 19(2): 245-252.

PICKNEY, J. L., D. F. MILLIE, K. E. HOWE, H. W. PAERL \& J. P. HURLEY. 1996. Flow scintillation counting of 14C-labeled microalgal photosynthetic pigments. Journal of Plankton Research, 18: 1867-1880.

QUAYLE, W. C., L. S. PECK, H. PEAT, J. C. ELLISEVANS \& P. R. HARRIGAN. 2002. Extreme responses to climate change in Antarctic lakes, Science, 295: 645.

ROCHERA, C., A. JUSTEL, E. FERNÁNDEZVALIENTE, M. BAÑÓN, E. RICO, M. TORO, A.
CAMACHO \& A. QUESADA. 2010. Interannual meteorological variability and its effects on a lake from maritime Antarctica. Polar Biology, 33: 1615-1628.

SCAR. 2003. Management Plan for Antarctic Specially Protected Area No. 126 Byers Peninsula, Livingston Island, South Shetland Islands. SCAR Bulletin 150, July.

SCHIAFFINO, M. R., F. UNREIN, J. M. GASOL, M. E. FARIAS, C. ESTEVEZ, V. BALAGUÉ \& I. IZAGUIRRE. 2009. Comparative analysis of bacterioplankton assemblages from maritime Antarctic freshwater lakes with contrasting trophic status. Polar Biology, 32: 923-936.

SCHIAFFINO, M. R., F. UNREIN, J. M. GASOL, M. RAMON, V. BALAGUÉ \& I. IZAGUIRRE. 2011. Bacterial community structure in a latitudinal gradient of lakes: the roles of spatial versus environmental factors. Freshwater Biology, 56: 19731991.

STEDMOND, C. A \& S. MARKAGER. 2005. Resolving the variability in dissolved organic matter fluorescence in a temperate estuary and its catchment using PARAFAC analysis. Limnology and Oceanography, 50: 686-697.

THINGSTAD, T. F. 2000. Control of bacterial growth in idealized food webs. In: Microbial Ecology of the Oceans. D.L. Kirchman (ed.): 261-288. John Wiley and Sons, New York.

TORO, M., A. CAMACHO, C. ROCHERA, E. RICO, M. BAÑÓN, E. FERNÁNDEZ-VALIENTE, E. MARCO, A. JUSTEL, M. C. AVEDAÑO, Y. ARIOSA, W. F. VINCENT \& A. QUESADA. 2007. Limnological characteristics of the freshwater ecosystems of Byers Peninsula, Livingston Island, in maritime Antarctica. Polar Biology, 30: 635-649.

VELÁZQUEZ, D., M. A. LEZCANO, A. FRIAS \& A. QUESADA. 2013. Ecological relationships and stoichiometry within a Maritime Antarctic watershed. Antarctic Science, 25: 191-197.

VILLAESCUSA, J. A., E. O. CASAMAYOR, C. ROCHERA, D. VELÁZQUEZ, A. CHICOTE, A. QUESADA \& A. CAMACHO. 2010. A close link between bacterial community composition and environmental heterogeneity in maritime Antarctic lakes. International Microbiology, 13: 67-77.

VILLAESCUSA, J. A., E. O. CASAMAYOR, C. ROCHERA, A. QUESADA, L. MICHAUD \& A. CAMACHO. 2013. Heterogeneous vertical struc- 
ture of the bacterioplankton community of a nonstratified Antarctic lake. Antarctic Science, 25: 229-238.

VINCENT, W. F. 2000. Microbial ecosystems of Antarctica (studies in polar research). Cambridge University Press, Cambridge.
WAGNER, M., R. AMMAN, H. LEMMER \& K. H. SCHLEIFER. 1993. Probing activated sludge with oligonucleotides specific for proteobacteria: inadequacy of culture-dependent methods for describing microbial community structure. Applied and Environmental Microbiology, 59: 1520-1525. 
